\title{
Demonstration on Replacement of Fine Aggregate with Quarry Dust in Plain Cement Concrete
}

\author{
S.Rajesh, K. Sathish kumar, Anish.C,
}

\begin{abstract}
Around 5\% of worldwide CO2 discharges originate from bond generation. Gas outflow is the consequence of fuel ignition and compound responses that occur in various phases of the procedure, principally in the clinker blazing stage. Amid the procedure of bond assembling, around 0.92 t of $\mathrm{CO} 2$ is discharged per ton of clinker delivered. This discharge for the most part originates from decarbonization of limestone, and the utilization of carbon energizes for warming (0.39 t). Normal CO2 outflows take up with processing procedures are 0.1 t of $\mathrm{CO} 2$ for each ton of concrete and originates from creation of power. The materials utilized incorporate Ordinary Portland Cement, quarry-tidy, waterway sand and water. Bond, Quarry clean and River sand are tried for their physical attributes according to the significant measures. The outcomes demonstrated that $30 \%$ substitution of quarry tidy gives more quality and it is appropriate for field works.
\end{abstract}

Keywords: Endolithic Bacteria, Calcium Carbonate, Self-healing, Biominerlization.

\section{INTRODUCTION}

\section{A. GENERAL}

In the development of structures and different structures, concrete assumes a huge part and an expansive quantum of cement is being used. The development organizations utilized the common assets from long decades as crude materials specifically. Waterway sand is one of the constituents utilized as a part of the generation of traditional cement has turned out to be very costly because of inordinate cost of transportation from common sources furthermore rare. Because of the persistent utilization of normal assets, for example, stream sand, the request increments definitely paying little mind to use. The expanding interest will proceed in future too. The expansion of pozzolanic materials enhances the mechanical

Revised Manuscript Received on October 22, 2019.

S.Rajesh, Asistant Professor, Department Of Civil Engineering,,Bharath Institution of Higher Education And Research,TamilNadu, India Email rajeshskr06@gmail.com

Anish.C, Assistant Professor, Department Of Civil Engineering,,Bharath Institution of Higher Education And Research,TamilNadu, India Email anishdavidpaul@gmail.com

K. Sathish kumar, Asistant Professor, Department Of Civil Engineering,,Bharath Institution of Higher Education And Research,TamilNadu, India Email sathish_4549@yahoo.co.in attributes of these lime mortars and contributes towards a higher strength. A further favorable position of lime pozzolan mortars is their lower ecological effect, when contrasted with concrete mortars, because of lower vitality utilization amid creation and $\mathrm{CO} 2$ retention via carbonation.[1]-[8]

\section{OBJECTIVE OF THE RESEARCH}

- To study the maximum usage of quarry rock waste as fine aggregates in mixtures by replacement of natural sand.

- To examine the effect quarry rock dust in the characteristic strength of concrete on compression strength test.

\section{SCOPE OF PROJECT}

- To give a most prudent cement.

- It ought to be effectively embraced in field.

- Using the loss in a valuable way.

- To lessen the expense of development.

- To make the most extreme use of locally accessible material.

- Minimize the greatest interest of stream sand.

\section{QUARRY ROCK DUST}

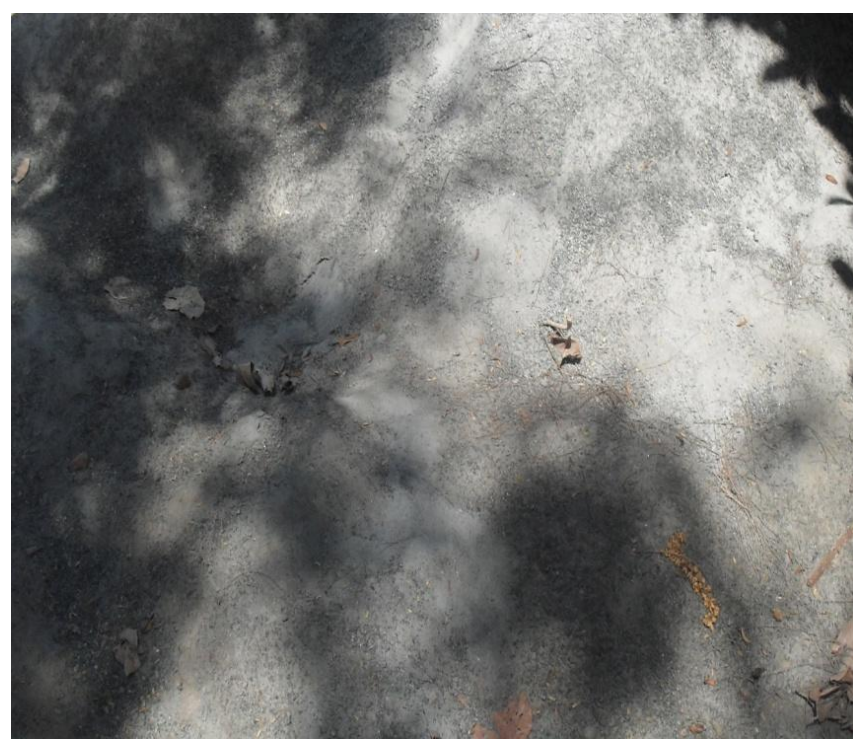


In prepared blend concrete regularly contains $25 \%$ - $30 \%$ of fine totals, made up of equivalent measure of quarry fines and sand. However, the measure of sand stone and molten shake fines utilizing as a part of the way was constrained, which produces drying shrinkage and different issues. Quarry shake tidy solid encounters better sulfate and corrosive resistance and its penetrability is less, contrasted with that of customary cement.[9]-[17]

\section{A. Quarry waste}

Quarry squander is gotten as a by-thing in the midst of the formation of aggregates through the staggering method of rocks in rubble smasher units. Using quarry waste as a substitute of sand being developed materials would resolve the natural issues achieved by the immense scale weariness of the typical wellsprings of conduit and mining sands. Commonly quarry squander is used as a piece of broad scale as a surface finishing material in freeways.

The compressive and part inflexible characteristics and robustness of concrete including quarry squander were better as differentiated and the conventional bond. Thus, the powerful use of quarry squander in first class and self-consolidating concretes could change this waste material into a gainful resource.[26]-[34]

B. Properties of quarry dust

As of now India has taken a noteworthy activity on building up the foundations, for example, express roadways, control ventures and mechanical structures and so on., to meet the prerequisites of globalization, in the development of structures and different structures concrete assumes the legitimate part and a substantial quantum of cement is being used. Waterway sand, which is one of the constituents utilized as a part of the generation of ordinary cement, has turned out to be exceptionally costly furthermore rare. In the setting of such a somber air, there is huge interest for option materials from mechanical waste.

\section{MATERIALS AND METHODS}

The materials utilized incorporate Ordinary Portland Cement, quarry clean, waterway sand and water. Concrete, Quarry clean and stream sand are tried for their physical qualities according to the important models. The Mortar solid shapes of size $50 \mathrm{~mm}$ are utilized for the assurance of compressive quality. Two control blends are set up with waterway sand as fine total and quarry tidy as fine total. The readied mortar is filled in $50 \mathrm{~mm}$ block shape and compacted utilizing a table vibrator. The examples are inundated in water for curing. Examples are removed from curing tank at assigned ages (7, 14 and 28 days) and tried for their compressive quality.[18]-[25]

\section{METHODOLOGY}

$\square$ Tested the material properties according to IS methodology.

$\square$ Mix structure for solid extent has been created according to Seems to be: 10262-2009.

Casted and relieved the solid examples according to IS systems.
The property of crisp cement was tried according to May be: $1199-1959$.

$\square$ The trademark quality of solidified solid example was tried according to Seems to be: 456-2000.

$\square$ Find the ideal substitution of ideal substitution.

$\square$ Compare the aftereffects of customary concrete and half substitution concrete

\section{RESULTS AND DISCUSSIONS}

\section{Compressive Test:}

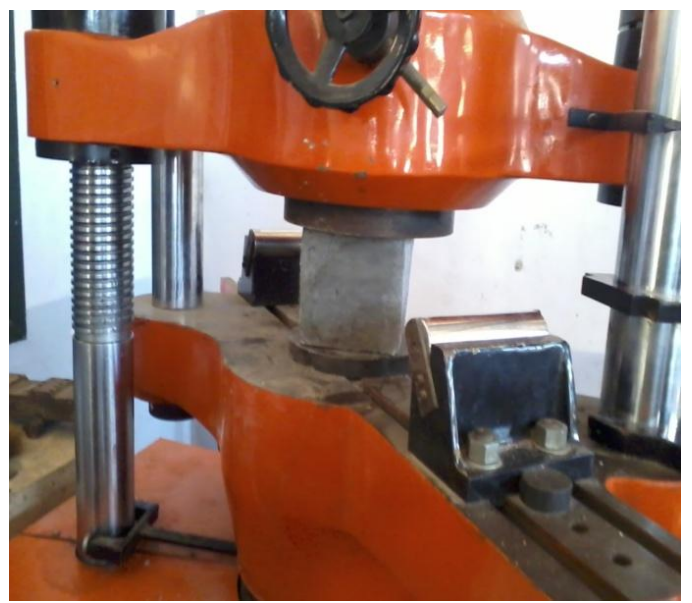

Series 1 - Conventional

Series 2 - $10 \%$ of Quarry dust

Series 3 - $20 \%$ of Quarry dust

Series $4-30 \%$ of Quarry dust

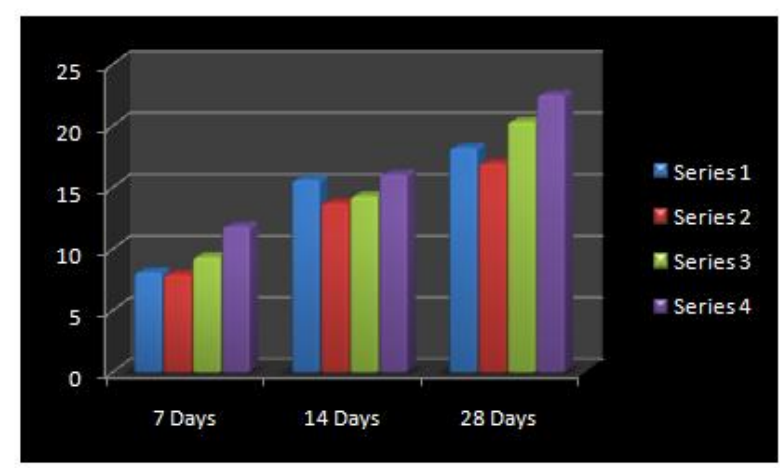

\subsubsection{Split Tensile TeST}



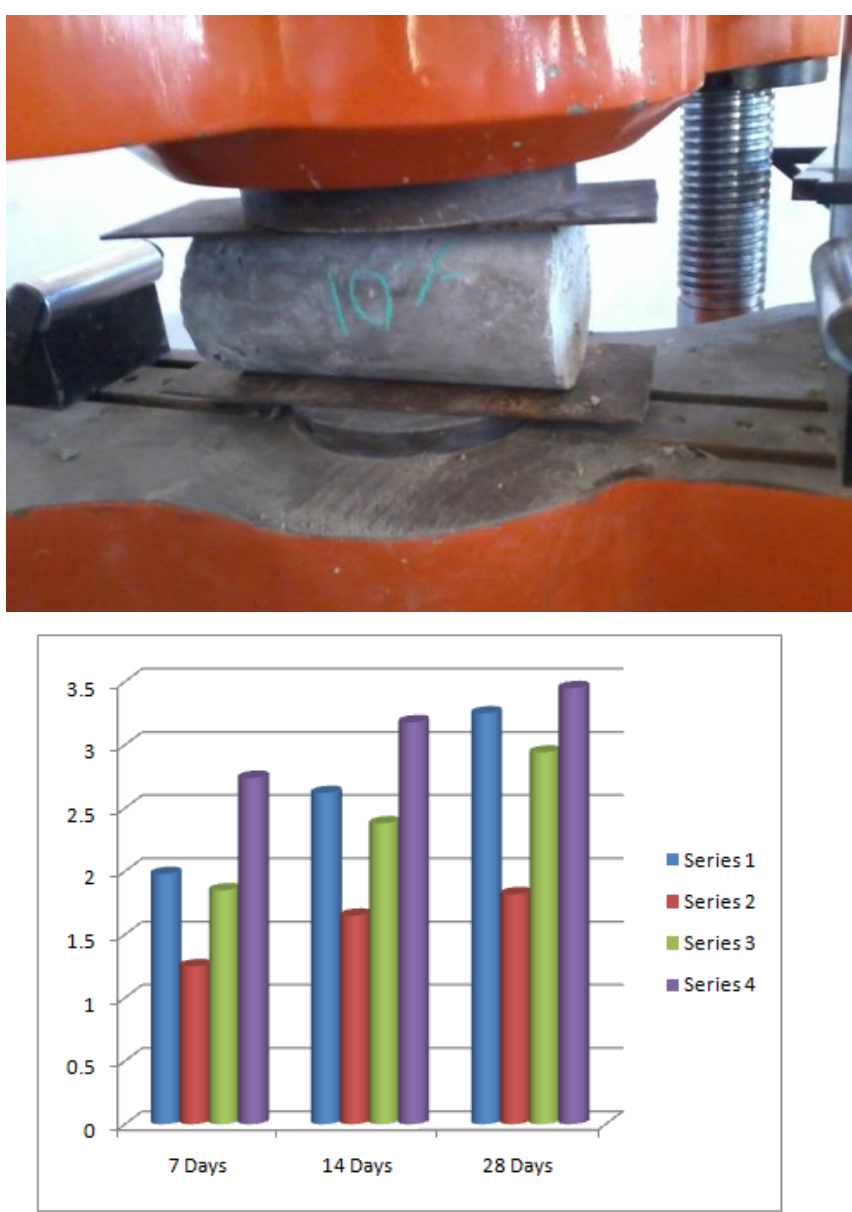

Series 1 - Conventional

Series $2-10 \%$ of Quarry dust

Series $3-20 \%$ of Quarry dust

\section{CONCLUSIONS}

It is likely affirmed that $30 \%$ substitution of quarry clean gives greater quality and it is appropriate for field works. Trademark stream sand, whenever superseded by hundred percent Quarry Rock Dust from quarries, may on occasion give proportionate or better than anything the reference concrete made with Natural Sand, similar to compressive and flexural quality examinations . Mulls over announced here and elsewhere have shown that the nature of Quarry Rock Dust bond is generally 10-12 percent more than that of similar mix of Conventional Concrete Thus, it tends to be induced that the overriding of trademark sand with Quarry Rock Dust, as full substitution in concrete is possible. In any case, it is judicious to do preliminary tossing with Quarry Rock Dust proposed to be used, remembering the ultimate objective to meet up at the water substance and mix degree to suit the necessary functionality levels and quality need. Regardless, more research considers are being made on Quarry Rock Dust strong significant for the practical utilization of Quarry Rock Dust as Fine Aggregate.

\section{REFERENCES}

1. Iyappan L., Dayakar P., Identification of landslide prone zone for coonoortalukusing spatial technology, International Journal of Applied Engineering Research,V-9,I-22,PP-5724-5732,Y-2014.

2. Kumar J., Sathish Kumar K., Dayakar P.,Effect of microsilica on high strength concrete, International Journal of Applied Engineering Research,V-9,I-22,PP-5427-5432,Y-2014.
3. Dayakar P., Vijay Ruthrapathi G., Prakesh J., Management of bio-medical waste, International Journal of Applied Engineering Research,V-9,I-22,PP-5518-5526,Y-2014.

4. Swaminathan N., Dayakar P., Resource optimization in construction project, International Journal of Applied Engineering Research,V-9,I-22,PP-5546-5551,Y-2014.

5. Venkat Raman K., Dayakar P., Raju K.V.B.,An experimental study on effect of cone diameters in penetration test on sandy soil, International Journal of Civil Engineering and Technology,V-8,I-8,PP-1581-1588,Y-2017.

6. Saritha B., Chockalingam M.P.,Photodradation of malachite green DYE using TIO2/activated carbon composite, International Journa of Civil Engineering and Technology,V-8,I-8,PP-156-163,Y-2017

7. Shendge R.B., Chockalingam M.P., Saritha B., Ambica A.,Swat modelling for sediment yield: A case study of Ujjani reservoir in Maharashtra, India,International Journal of Civil Engineering and Technology,V-9,I-1,PP-245-252,Y-2018

8. Chockalingam M.P., Balamurgan V.,Modernisation of an existing urban road-sector in Chennai, a case study report,International Journal of Civil Engineering and Technology,V-8,I-8,PP-1457-1467,Y-2017

9. Saritha B., Chockalingam M.P.,Adsorption study on removal of basic dye by modified coconut shell adsorbent, International Journal of Civil Engineering and Technology,V-8,I-8,PP-1370-1374,Y-2017

10. Saritha B., Chockalingam M.P.,Adsorptive removal of heavy metal chromium from aqueous medium using modified natural adsorbent,International Journal of Civil Engineering and Technology,V-8,I-8,PP-1382-1387,Y-2017

11. Chockalingam M.P., Palanivelraja S.,Retrospective analysis of a theoretical model used for forecasting future air quality near the north Chennai thermal power plant,International Journal of Civil Engineering and Technology,V-8,I-8,PP-1457-1467,Y-2017

12. Saritha B., Chockalingam M.P.,Photodegradation of methylene blue dye in aqueous medium by $\mathrm{Fe}-\mathrm{AC} / \mathrm{TiO} 2$ Composite,Nature Environment and Pollution Technology,V-17,I-4,PP-1259-1265,Y-2018

13. Shendge R.B., Chockalingam M.P., Kaviya B., Ambica A.,Estimates of potential evapotranspiration rates by three methods in upper Bhima Basin, In Maharashtra, India,International Journal of Civil Engineering and Technology,V-9,I-2,PP-475-480,Y-2018

14. Shendge R.B., Chockalingam M.P.,The soil and water assessment tool for Ujjani Reservoir,International Journal of Mechanical Engineering and Technology,V-9,I-2,PP-354-359,Y-2018

15. Shendge R.B., Chockalingam M.P.,A review on soil and water assessment tool,International Journal of Mechanical Engineering and Technology,V-9,I-2,PP-347-353,Y-2018

16. Sachithanandam P., Meikandaan T.P., Srividya T.,Steel framed multi storey residential building analysis and design,International Journal of Applied $\quad$ Engineering Research,V-9,I-22,PP-5527-5529,Y-2014

17. Meikandaan T.P., Ramachandra Murthy A.,Study of damaged RC beams repaired by bonding of CFRP laminates, International Journal of Civil Engineering and Technology,V-8,I-2,PP-470-486,Y-2017

18. Meikandaan T.P., Ramachandra Murthy A.,Retrofittng of reinforced concrete beams using GFRP overlays,International Journal of Civil Engineering and Technology,V-8,I-2,PP-423-439,Y-2017

19. Meikandaan T.P., Ramachandra Murthy A.,Flexural behaviour of RC beam wrapped with GFRP sheets,International Journal of Civil Engineering and Technology,V-8,I-2,PP-452-469,Y-2017

20. Meikandaan T.P., Murthy A.R.,Experimental study on strengthening of rc beams using glass Fiber,International Journal of Civil Engineering and Technology,V-9,I-11,PP-959-965,Y-2018

21. Meikandaan T.P., Hemapriya M.,Use of glass FRP sheets as external flexural reinforcement in RCC Beam,International Journal of Civil Engineering and Technology,V-8,I-8,PP-1485-1501,Y-2017

22. Saraswathy R., Saritha B.,Planning of integrated satellite township at Thirumazhisai,International Journal of Applied Engineering Research,V-9,I-22,PP-5558-5560,Y-2014 
23. Saritha B., Ilayaraja K., Eqyaabal Z.,Geo textiles and geo synthetics for soil reinforcement,International Journal of Applied Engineering Research,V-9,I-22,PP-5533-5536,Y-2014

24. Ambica A., Saritha B., Changring G., Singh N B., Rajen M., Salman Md.,Analysis of groundwater quality in and around Tambaram taluk, Kancheepuram district,International Journal of Civil Engineering and Technology,V-8,I-8,PP-1362-1369,Y-2017

25. Arunya A., Sarayu K., Ramachandra Murthy A., Iyer N.R.,Enhancement of durability properties of bioconcrete incorporated with nano silica,International Journal of Civil Engineering and Technology,V-8,I-8,PP-1388-1394,Y-2017

26. Ilayaraja K., Krishnamurthy R.R., Jayaprakash M., Velmurugan P.M., Muthuraj S.,Characterization of the 26 December 2004 tsunami deposits in Andaman Islands (Bay of Bengal, India),Environmental Earth Sciences, V-66,I-8,PP-2459-2476,Y-2012

27. Ilayaraja K.,Morphometric parameters of micro watershed in Paravanar sub-basin, Cuddalore District,International Journal of Civil Engineering and Technology,V-8,I-8,PP-1444-1449,Y-2017

28. Ilayaraja K., Singh R.K., Rana N., Chauhan R., Sutradhar N.,Site suitability assessment for residential areas in south Chennai region using remote sensing and GIS techniques,International Journal of Civil Engineering and Technology,V-8,I-8,PP-1468-1475,Y-2017

29. Ilayaraja K., Reza W., Kumar V., Paul S., Chowdhary R.,Estimation of land surface temperature of Chennai metropolitan area using Landsat images,International Journal of Civil Engineering and Technology,V-8,I-8,PP-1450-1456,Y-2017

30. Chitra R.,Experimental study on beam using steel fiber and latex,International Journal of Civil Engineering and Technology,V-8,I-8,PP-1395-1403,Y-2017

31. Chitra R.,Analysis of traffic and management at Kovilambakkam intersection,International Journal of Civil Engineering and Technology,V-8,I-8,PP-1433-1443,Y-2017

32. Aswathy M.,Experimental study on light weight foamed concrete,International Journal of Civil Engineering and Technology,V-8,I-8,PP-1404-1412,Y-2017

33. Aswathy M.,Wastewater treatment using constructed wetland with water lettuce (Eichornia Crasipies),International Journal of Civil Engineering and Technology,V-8,I-8,PP-1413-1421,Y-2017

34. Kiruthiga K., Anandh K.S., Gunasekaran K, Assessment of influencing factors on improving effectiveness and productivity of construction engineers, 2015, International Journal of Applied Engineering Research, V - 10,I -17,p -13849-13854.

\section{AUTHORS PROFILE}

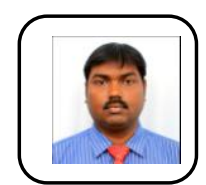

S.Rajesh, Asistant Professor, Department Of Civil Engineering,,Bharath Institution of Higher Education And Research,TamilNadu, India

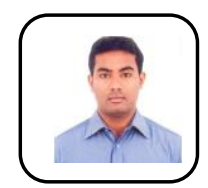

Anish.C Assistant Professor,,Department Of Civi Engineering,,Bharath Institution Of Higher Education And Research,TamilNadu, India .

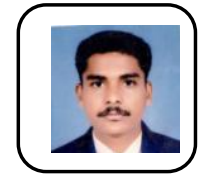

K. Sathish kumar, Asistant Professor, Department Of Civil Engineering,,Bharath Institution of Higher Education And Research,TamilNadu, India 